\title{
THE NEXUS OF GOVERNMENT SPENDING, PRICE, OUTPUT, AND MONEY IN THE ECOWAS SUB-REGION: EVIDENCE FROM PANEL ARDL AND CAUSALITY APPROACH
}

\author{
Matthew Abiodun DADA ${ }^{1}$, Sunday Mauton A. POSU ${ }^{2}$, \\ Osaretin Godspower OKUNGBOWA ${ }^{3}$, Bamidele P. ABALABA ${ }^{4}$ \\ ${ }^{1,2}$ Federal University of Agriculture, Abeokuta, Nigeria \\ ${ }^{3}$ National Institute for Legislative and Democratic Studies, Abuja, Nigeria \\ ${ }^{4}$ Osun State University, Osogbo, Nigeria \\ Corresponding author's e-mail: mattabeyvoice2@yahoo.com
}

\begin{abstract}
The question of how macroeconomic variables dynamically interact is very crucial in any broad-based economic integration aiming at expanding economic growth and living standard in any human society. This study examined the nexus of government spending, price, output, and money in the ECOWAS sub-region using panel ARDL and causality approach. Data covering the period (1981-2019) were collected mainly from the latest version of the World Development Indicators. The result showed a positive relationship between government spending with GDP, import, exchange rate, unemployment rate, and population growth rate but a negative relationship between government spending with inflation, money supply, export, and interest rate. The result further showed short-run unidirectional causality running from government spending to inflation, money supply to inflation as well as money supply to GDP. Short-run bi-directional causality existed between GDP and inflation but none between government spending and GDP nor between government spending and money supply. The result of long-run Granger causality test showed bi-directional causality between government spending with inflation, government spending, and money supply; GDP and inflation; and GDP and money supply. Unidirectional causality ran from GDP to government spending; and money supply to inflation. The overall implication of this study established that an increase in government spending lowered inflation and raised the living standard of people in the ECOWAS sub-region in the long run. The study therefore concluded that any rise in import, unemployment rate, exchange rate, and population growth rate would raise government spending growth rate in the short run; and an increase in government spending would shrink inflation and boost economic growth and living standard in the long run.
\end{abstract}

Keywords: Causality approach, Economic growth, ECOWAS sub-region, Government spending, Inflation, Panel ARDL.

JEL Classification: B22, E23, F43, O47, E31

C2021 Matthew Abiodun Dada, Sunday Mauton A. Posu, Osaretin Godspower Okungbowa, Bamidele P. Abalaba. This is an open access article licensed under the Creative Commons Attribution License (http://creativecommons.org/ licenses/by/4.0). 


\section{INTRODUCTION}

Every economy, be it developed, emerging or developing as country-specific, regional or global usually has concern over the behaviour of some key macroeconomic variables, namely the general price level, interest rate, exchange rate, unemployment rate, to mention a few. How variables dynamically interact with one another is of great interest to policy makers and scholars alike. For instance, when the general price level begins to rise, there is always a great concern to every stakeholder in the economy because of the effects this continuous increase could have on real wage and purchasing power in the economy. What could be the implications of this situation on aggregate demand and aggregate supply?

Many observers would be wondering about the cause of this continuous increase in the general price level. Could it be because of too much money pumped into circulation? Could it be because of high cost of production due to high cost of credit and exchange rate fluctuations that negatively affect the real sector? It could also be linked to the tax policy, which could raise the market prices of goods and services. The scenario, in this case, is that of having one problem but diagnosed with many likely causes. The policy to tackle this menace will also be set up by the government, but to derive the right policy, the situation needed to have been well diagnosed. The derivation of optimal policy to deal with most of the macroeconomic problems requires the knowledge of how these variables dynamically interact. Unfolding whether there is a cause-effect relationship among these variables is a key in policy design.

The question of how macro-variables such as price, money, output, and government spending affect each other in the economy, therefore, is crucial in this study. In the recent time, research has focused on the dynamic behaviour between government spending individually with economic growth, and inflation; inflation and economic growth; and so on. Some more recent studies have increased the scope of investigation to include money and output with country-specific studies on a larger scale. Understanding the dynamic interactions among government spending, price, output, and money, with consideration to import and export of goods and services, exchange rate, unemployment rate, interest rate, and population growth rate at the regional level is crucial for regional economic growth and development.

The impact of government actions or dominance in the economy can be evaluated based on the outcomes of this kind of debate. Adequate knowledge of government spending, price, output, and money nexus helps in the evaluation of government policy efficacy in the macroeconomic management of the economy. The issue relating to dynamic interaction among government spending, price, output, and money is very germane to policy makers and economic analysts as well as investors whose main objective is to maximize profit. Although there are several studies on government spending and some macroeconomic variables like inflation and economic growth, there are limited studies on the dynamics of government spending, price, output, and money. Where such studies exist, they are mostly country-specific or cross-country studies based on time series econometric modelling approach. 
The study on the dynamics of government spending, price, output, and money is very important since government spending itself could be affected by price, output, and money likewise these variables, too, can equally affect government spending. These effects might not occur contemporaneously but on a lagged basis. The trend in government spending varies from time to time. As political leadership changes, so also the trend in prices, output, and money and the expected nexus among these variables. Going by theory, many factors have been suggested to determine the level and size of government spending.

Price is a determining factor of nominal government spending. For instance, government spending might be increasing only in nominal term due to inflation but this might not be so in real term. Hence, inflation becomes a factor. On the other way round, increased spending in real term will raise aggregate demand, and if nothing is done to boost output in the real sector to make aggregate supply to increase, inflation will set in since demand would have gone in excess of supply leading to demand-pull inflation. The policy response could be lowering of government spending in order to reduce aggregate demand.

On the contrary, there is deficiency in demand when the economy is closer to or is in recession due to business cycle when a low level of inflation is expected in a situation. During this period, price is expected to move sluggishly. The policy response to this situation is to raise government spending to boost aggregate demand. Among the existing studies on government spending and inflation, a few of the studies captured money or output. Output and money are very important in the determination of government spending and inflation (Aksoy and Melina, 2011; Kia, 2006; Magazzino, 2011; Ozurumba, 2012; Pekarski, 2011; Ssebulime and Edward 2019; Tehranchian et al., 2010).

The recent studies that extended the variables to include output and money are mainly country-specific. The contention in most of these studies is the question of the direction of causality between inflation to government spending: unidirectional, bi-directional, or no causality. This contention continues to generate mixed reactions among scholars notwithstanding the nature, scope, and methods of study. The nature of investigation and empirical findings vary across studies. The nonconsensus in findings on the dynamics of government spending, price, output, and money calls for more studies as this one.

Keynesian economic writers are keen on finding out the efficacy of fiscal policy action of government in combating inflation by modelling causality relation between the two variables. Trend in government expenditure and consumer prices in some developing countries, as in the Nigerian case, revealed a continuous fall in purchasing power along with an increase in government expenditure. With an increase in nominal income, consumers still get only fewer goods. The scenario depicts money illusion, which is characterized by falling standard of living and surge in socio-economic vices.

Output is expected to respond positively to any increase in money reward in form of increased wages, but if not, it means such an increase is only in terms of nominal wage and not the real wage. An increase in nominal wage without a corresponding increase in output would eventually translate into inflation and loss of welfare. West African region has undergone a deteriorating condition of living 
in the recent time with increased agitation among the various labour unions clamouring for wage increase and better condition of living due to falling purchasing power and loss in real income arising from price fluctuations. If those that are working cannot comfortably afford to secure the basic needs of life such as food, clothing, and shelter, one wonders what happens to those who are not working! What is the hope of unemployed and dependent population? The dependency ratio is rising as population and unemployment rate increases raising demand for goods and services without a compensatory increase in supply, forcing the prices of goods and services to be on the increase. The lack of a compensatory increase in supply is an evidence of irresponsiveness of output to increase in money wage.

There is a question of whether output is also favourably responding to any increase in money supply. Further clarification is still required on the Granger causation between changes in government spending and inflation in the affected ECOWAS countries. Another common economic illness is weak currency, which makes imported goods more expensive while locally made goods become cheaper at the international market. The weak currency syndrome could hinder the industrial development especially in a region where most of the capital input needed in the manufacturing sector is imported. The problem of exchange rate instability will limit the growth of the manufacturing sector and this will hinder the growth of the real sector to catch up with the money sector. This study has developed a panel regression on the nexus among government spending, price, output, and money in the ECOWAS sub-region.

Prior studies scarcely considered the growth in income and population in the determination of government spending-inflation nexus. The growth in nominal income may lead to inflation if it is not properly managed. Excessive population growth may raise the level of demand and may eventually degenerate into demandpull inflation if such a high population growth rate does not, in any way, induce output growth rate. This study is one of the limited studies aiming at testing the cause-effect relationship in this economic sub-region but unique in the use of panel ARDL and causality approach with consideration to gross domestic product, money supply, export trade, import trade, exchange rate, population growth rate, unemployment rate and interest rate. Such a study is scarce in the region.

This study is further structured as follows: Section 2 captures the theoretical and empirical literature on government spending with the key macroeconomic variables such as output, price, and money. The research method is presented in Section 3, while Section 4 embodies the empirical analysis and discussion of results. Section 5 concludes the study.

\section{THEORETICAL AND EMPIRICAL LITERATURE REVIEW}

This study is hinged on the fiscal theory of the price level as well as the Wagnerian and Keynesian theories. Wagner and the Wagnerians portray government spending as an endogenous factor that is determined by output of the economy. Keynes and the Keynesians evaluate government spending as an exogenous policy instrument to influence economic output. These schools of 
thought share an opposing view on the direction of causality between the two variables. To Keynes, causality runs from government spending to output, whereas to Wagner, causality runs from output to government spending. It should be noted that the role of government spending on price depends largely on the magnitude of the influence of such spending on output. If it has greater influence on output than on price, it may not generate inflation but if it happens the other way round, the outcome is inflation.

The fiscal theory of the price level proposes that government's fiscal policy affects the price level. The deliberate action of government to raise or lower expenditure has implications on the general price level. This implies that a stable price level requires sustainable government finances. That is, the government must execute balanced budget throughout the business cycle, and must not implement budget deficit. When the government decides to hike or lower its spending, inflation may set in. This scenario explains unidirectional causality from government spending to inflation. It supports the Keynesian view that fiscal policy is a veritable tool to combat inflation. This is a kind of heretical economic theory in contrast to the mainstream theory of the price level.

The price theory explains the general price level as primarily or exclusively determined by money supply in the long run, and therefore, supports unidirectional causality from money supply to inflation. Inflation is the result, and not the cause, of expansion in money supply. Thus, according to the fiscal theory, if a government has an unsustainable fiscal policy, the government will fail to pay off its obligation in future out of tax revenue. The government can only pay off its future obligation by running a structural deficit, as inflation erodes the value of the debt away. Fiscal discipline requires a balanced budget over the course of the business cycle. Invariably, the government must run surplus budgets in the period of expansions but deficit budgets only in contractions. This approach is necessary for the price level to remain stable, eliminating unsustainable deficits, which will always fuel inflation in future. Prices, therefore, respond differently to different fiscal regimes. The relationship between government spending and inflation crucially explains how sustainable fiscal policy and efficacy of Keynesian fiscal policy are to the economy.

Magazzino (2011) investigated public expenditure and inflation for the Mediterranean countries over the period of 1970-2009. The preliminary analysis showed that the ratio of public expenditure / GDP was $I(1)$, while consumer price index was $I(2)$. Further analysis indicated a long-run relationship between public expenditure and inflation for Portugal only. The short-run causality test indicated a unidirectional flow from government expenditure to inflation for Cyprus, Malta, and Spain; and from inflation to public expenditure for France. The test reported bidirectional causality for Italy.

Pekarski (2011) investigated budget deficits and inflation in high inflation economies and established recurrent outbursts as contributing to extreme inflation in those economies. Ezirim and Ofurum (2003) used Clark's hypothesis, and the share of government spending in GDP as a measure of public sector. The study established that aggregate supply reduced whenever the size of the public sector exceeded a certain threshold. The result concluded that high tax burden discouraged the incentives to produce and aggravate inflation. 
Ezirim, Muoghalu, and Elike (2008) performed a study on the relationship between government spending growth and inflation in the United States of America over the period of 1970-2002. The study established a bi-directional causality, and a long-run equilibrium relationship between government spending and inflation. Inflation and government spending had significantly positive effects on each other in the United States of America. This study found support for the Keynesian theory: Reduction in government spending would bring down inflation while reduction in price dynamics would cause government spending to fall. The implication of the study was that fiscal policy could be a powerful tool for controlling inflation.

Georgantopoulos and Tsamis (2010) examined the interrelationship among money supply, prices, government spending, and economic growth between 1980 and 2009 for Cyprus. The result showed a positive relationship between government spending and economic growth but a negative relationship between inflation and economic growth. The conclusion was that government spending caused inflation in Cyprus. Dada and Abalaba (2013) used trivariate RVAR models to investigate the causal link between inflation and government expenditure over the period of 1961-2011 in Nigeria. The study found a long-run unidirectional causal flow from inflation to government spending but failed to support the feedback hypothesis, and succinctly concluded that inflation was a cause rather than the effect of increase in government expenditure in Nigeria.

Bwire and Nampewo (2014) investigated the dynamic links among money, inflation, and budget deficit for Ugandan. The authors employed a vector error correction modelling approach and pairwise Granger causality on quarterly data from 1999Q4 to 2012Q3. A unidirectional causality flow from inflation to budget deficit with no reverse causation running from budget deficit to inflation was found. Budget deficit and money supply had no causal link. Mallik and Chowdhury (2001) conducted a study on inflation and economic growth in four South Asian countries: Bangladesh, India, Pakistan, and Sri-Lanka. The existence of a long-run positive relationship between inflation and economic growth was established in the four countries. Significant bidirectional feedback between inflation and economic growth existed. The study concluded that moderate inflation was good for economic growth but that faster economic growth could spark off inflation in the four South Asian countries.

Dada, Posu, and Maghori (2017) used modified forms of ARDL, UVAR, and Granger non-causality models to investigate inflation and economic growth in five ECOWAS countries during the period of 1981-2013. The bivariate analysis of time series data revealed a long-run positive relationship between inflation and economic growth in two countries only, and a short-run negative inflationary effect on growth in four of the countries. The UVAR-based modified Granger non-causality test found no causality between economic growth and inflation in the five countries.

Attari and Javed (2013) investigated the existing interrelationships among inflation, economic growth, and government spending in Pakistan during the period of 1980-2010. The study confirmed long-run relationships among inflation, economic growth, and government with government spending yielding positive externalities and linkages. In the short run, while government spending had effects on economic growth, inflation had nil effect. The causality tests showed that 
inflation caused economic growth, and economic growth caused government spending. Ssebulime and Edward (2019) modelled budget deficit and inflation nexus in Uganda during the period of 1980-2016. The result established a unidirectional causality where budget deficit Granger-caused inflation, and concluded that government spending was a cause and not the result of inflation in Uganda.

\section{DATA AND ECONOMETRICS METHODOLOGY}

The study follows panel econometric procedures using panel data spanning the period of 1991-2018 across 12 ECOWAS countries. The data were obtained on total government spending, consumer price index, population growth rate, exchange rate, unemployment rate, interest rate, imports, exports, money supply, and gross domestic product. Data for this study were sourced mainly from the latest version of the World Development Indicators (WDIs). This is augmented with World Economic Outlook (WEO), and Apex Bank Data Base of each country involved in the analysis.

\subsection{Model Specifications}

The simple model derives its base from theoretical framework on the fiscal theory of price level. The theory states that fiscal policy affects the price level. Achievement of price stability requires that government finances be sustainable such that government expenditure is always equal to government revenue. Accordingly, the price $(P)$ is expressed as a function of fiscal policy $\left(F^{\mathrm{p}}\right)$, which establishes the functional relationship between fiscal policy and price.

$$
P=f\left(F^{\mathrm{p}}\right),
$$

where $F^{\mathrm{p}}=(G E, G R) ; G E=$ total government expenditure.

$$
G R=\text { Total Government Revenue. }
$$

$G E=G R$ implies sustainability in government finances. Hence, either $G E$ or $G R$ can be used to explain the price behaviour. Government can influence the behaviour of some key macroeconomic variables in the economy, particularly the price level, through fiscal policy. Government can hike expenditure or cut taxes in order to achieve a given macroeconomic objective. Government may be interested in influencing output and employment through fiscal actions. In this case, the relationship between price and fiscal policy represented by either of $G E$ or $G R$ can be determined by replacing $F^{\mathrm{p}}$ in Eq. (1) with $G E$. The amount of money collected as revenue is what is spent as expenditure, in the case of a balanced budget. By that, Eq. (1) transforms into:

$$
P=f(G E) .
$$

Since there is possibility for feedback in this relationship, Eq. (3) can also transform into:

$$
G E=f(P)
$$


Incorporating other variables that connect to these two important variables in this study, Eqs. (3) and (4) transform into Eqs. (5) and (6), respectively, as:

$$
\begin{gathered}
P=f(G E, G D P, M S, E X, I M, F M, P R, E R, I R, U R), \\
G E=f(P, G D P, M S, E X, I M, F M, P R, E R, I R, U R),
\end{gathered}
$$

where $P$ - price dynamics captured by inflation rate; $G E$ - growth rate of government spending; $G D P$ - growth rate of gross domestic products; $M S$ - growth rate of money supply; $E X$ - growth rate of export; $I M$ - growth rate of import; $F M$ - growth rate of financial market; $P R$ - growth rate of population; $E R$ - local currency to US dollar exchange rate; $I R$ - interest rate; $U R$ - unemployment rate.

\subsection{Unit Root Tests}

Unit root test is a necessary condition that must be satisfied in this study. To account for the statistical properties of the variables involved in the analysis, this study employed panel unit root tests as proposed by LLC (Levin, Lin, and Chu, 2002) and IPS (Im, Pesaran, and Shin, 2003). The null of hypothesis of 'serial unit contains root' is tested against an alternative hypothesis of 'serial unit does not contain root.' For a serial unit to contain root, it means the series is non-stationary. On the other hand, for a serial unit to contain no root, it means the series is said to be stationary. When a serial unit is stationary, it has zero mean and constant variance. The LLC unit root regression equation having a test statistic with standard normal distribution is of the form

$$
\Delta \boldsymbol{R}_{i, t}=\phi^{*} \boldsymbol{R}_{i, t-1}+\sum_{L=1}^{p i} \beta_{i L} \Delta \boldsymbol{R}_{i, t-L}+\lambda_{m i} \mathrm{~d}_{m t}+\varepsilon_{i, t},
$$

where $\boldsymbol{G}$ - vector of variables in the study; $m$ - available models for consideration ranging from Model 1, Model 2 and Model 3; pi - unknown lag order that is allowed to vary across individuals; $i$ - number of cross-sectional units; $t$ - time period; $\Delta$ - first difference operator; $\boldsymbol{R}_{i, t}$ - has an individual-specific mean, linear, and individual-specific time trend; $\phi, \beta, \lambda$ - estimated parameters; $\varepsilon$ - white noise error term.

The null hypothesis of unit root is tested against the alternate hypothesis of no unit root

$$
\begin{aligned}
& H_{0}: \phi^{*}=0, \text { for all } i \\
& H_{0}: \phi^{*}<0, \text { for all } i .
\end{aligned}
$$

The study considers Model 3 in which case $\left(m=3 ; d_{m t}=d_{3 t}=\{1, t\}\right.$. The series $\boldsymbol{R}_{i, t}$ has an individual-specific mean, linear, and individual-specific time trend. Similarly, the IPS unit root regression equation to estimate in this study is of the form specified in Eq. (8).

$$
\Delta \boldsymbol{R}_{i, t}=\eta^{*}{ }_{i} \boldsymbol{R}_{i, t-1}+\sum_{j=1}^{P i} \xi_{i j} \Delta \boldsymbol{R}_{i, t-j}+\Psi_{m i} \mathrm{~d}_{m t}+\varepsilon_{i, t},
$$

where $\boldsymbol{R}$ - vector of variables in the study; $m$ - available models for consideration, $m=1,2,3 ; p i-$ lag order that is allowed to vary across individuals; $i$ - number of cross-sectional units; $t$ - time period; $\Delta-$ first difference operator; $\phi, \beta, \lambda-$ 
estimated parameters; $\varepsilon$ - white noise error term.

The null hypothesis $\left(H_{0}\right)$ of unit root is tested against the alternate hypothesis $\left(H_{1}\right)$ of no unit root

$$
\begin{gathered}
H_{0}: \eta^{*}{ }_{i}=0, \text { for all } i ; \\
H_{1}: \eta^{*}{ }_{i}<0, \text { for all } i=1, \ldots, N_{1} ; \\
\eta^{*}{ }_{i}=0 \text { for } i=N_{1}+1, \ldots, N .
\end{gathered}
$$

The same pattern under LLC is applied. Hence, Model 3 is equally applied such that $\left(m=3 ; \mathrm{d}_{m t}=\mathrm{d}_{3 t}=\{1, t\}\right.$ in which case the series $\boldsymbol{R}_{i, t}$ has an individualspecific mean, linear, and individual-specific time trend.

\subsection{Panel ARDL}

This study applies a panel autoregressive distributed lag modelling approach due to the statistical properties exhibited by the study variables, which appeared to be a mixed order of integration. The unrestricted panel ARDL model takes the form

$$
\boldsymbol{S}_{i, t}=\mu_{i}+\sum_{j=1}^{p} \phi_{i, j} \boldsymbol{S}_{i, t-j}+\sum_{j=1}^{q} \Omega_{i, j} \boldsymbol{T}_{i, t-j}^{*}+\varepsilon_{i, t},
$$

where $\boldsymbol{T}_{i, t-j}^{*}-K \times 1$ vector of explanatory variables for group $i$; $\mu_{i}$ - the fixed effects; $t=1,2, \ldots, T$ time periods; and $i=1,2, \ldots, N$ countries; $\varepsilon_{i, t}$ - the error term; $p, q$-each represents a balanced panel that vary not across countries. form

By re-parameterizing the model, it becomes a restricted ARDL model of the

$$
\Delta \boldsymbol{S}_{i, t}=\mu_{i}+\sum_{j=1}^{p-1} \xi_{i, j} \Delta \boldsymbol{S}_{i, t-j}+\sum_{j=1}^{q-1} \eta_{i, j} \Delta \boldsymbol{T}_{i, t-j}^{*}+\beta_{i}^{*} e c m_{t-1}+\varepsilon_{i, t} .
$$

Expressing Eq. (10) more explicitly, it becomes

$$
\begin{gathered}
\Delta \boldsymbol{S}_{i, t}=\mu_{i}+\sum_{j=1}^{p-1} \xi_{i, j} \Delta \boldsymbol{S}_{i, t-j}+\sum_{j=1}^{q-1} \eta_{i, j} \Delta \boldsymbol{T}_{i, t-j}^{*} \\
+\beta_{i}^{*}\left(\boldsymbol{S}_{i, t-1}-\psi_{i} \boldsymbol{T}_{i, t-1}^{*}\right)+\varepsilon_{i, t},
\end{gathered}
$$

where $\psi_{i}$ - the long-run coefficients; $\beta_{i}^{*}$ - the coefficients of the error correction terms with one period lag.

The criterion used for optimal lag selection is Schwarz information. The pooled mean group restriction is that the elements of $\psi$ are common across countries.

\subsection{Test of Causality}

The confirmation of long-run relationship from the panel ARDL gives the indication of causality at least in one direction. In order to ascertain the direction of causality and the fact that standard causality test fails to provide cross-sectional results in heterogeneous panel data models, this study employs Dumitrescu-Hurling Granger non-causality test. Dumitrescu and Hurling (2012) developed this alternative test to determine the Granger non-causality in heterogeneous panel series. The model is of the form 


$$
Y_{i, t}=\delta_{i}+\sum_{p=1}^{P} \psi_{i}^{(p)} Y_{i, t-p}+\sum_{p=1}^{P} \eta_{i}^{(p)} X_{i, t-p}+\varepsilon_{i, t} .
$$

$Y$ and $X$ represent any pair of variables. This procedure uses an average Wald test to test the null hypothesis of homogeneous non-causality from either of variable $Y$ to $X$ against the alternate hypothesis of causality from variable $X$ to $Y$ for at least one cross-section. Equation (12) can only be interpreted as long-run causality. To account for causality in the short-run between any pair of variables $Y$ and $X$, a model similar to Eq. (12) is estimated, but with variables $Y$ and $X$ entering the model in their first differences. It is the model for short-run causality between variables $Y$ and $X$ and it is specified of the form

$$
\Delta Y_{i, t}=\delta_{i}+\sum_{p=1}^{P} \Psi_{i}^{(p)} \Delta Y_{i, t-p}+\sum_{p=1}^{P} \eta_{i}^{(p)} \Delta X_{i, t-p}+\varepsilon_{i, t} .
$$

All variables are as previously defined.

\subsection{Variable Description and Measurement}

Key variables in this study are stated and described as follows. Inflation rate: it is measured by natural logarithm of consumer price index. Growth rate of government spending: it is measured by natural logarithm of total government expenditure. Growth rate of gross domestic product: it is measured by natural logarithm of gross domestic product in current US dollar. Growth rate of money supply: it is measured by natural logarithm of broad money (M2). Population growth rate: it is measured in percentage. Export growth rate: it is measured by natural logarithm of export of goods and services. Import growth rate: it is measured by natural logarithm of total import of goods and services. Unemployment rate: it is measured by labour force divided by total population times one hundred. Unemployment rate is expressed in percentage. Interest rate on credits: it is the interest charges made available by the financial market to drive investment activities.

The major role of banks and other financial institutions, in any economy, is to ensure effective mobilization of savings for the purpose of investment. This prevents the scenario of idle or redundant fund, ensures a financial inclusiveness, and provides sufficient financial resources to where they are optimally needed for productive and entrepreneurial activities. Financial institutions also checkmate all forms of financial mismanagement that could cumulate into the money sector outgrowing the real sector. These functions are very germane in the realization of any growth and development initiatives of the economy. Finally, the exchange rate of local currency unit to US dollar was also considered as a variable in this study. A decrease or an increase in exchange rate shows how the currency gains or loses value relative to US dollar. It shows whether a given currency is waxing stronger or getting weaker on a daily basis.

\section{EMPIRICAL ANALYSIS}

This section describes the statistical properties of the data employed for modelling this study. It includes the presentation and discussion of empirical results. Data scrutiny and testing are necessary conditions in any empirical study. 
The information on the distribution of a given data set as well as the statistical properties help the researcher(s) on the choice of appropriate method of analysis and prevent or reduce the possibility of committing errors capable of rendering the findings null and void, which could make recommendations misleading and counterproductive.

\subsection{Descriptive Summary of the Study Variables}

This study employs the descriptive analysis of the variables. The result of the descriptive analysis is presented in Table 1 . The average government spending across sample and across time stood at about (2.22 billion US dollar) with an average index of consumer prices stood at about (82.9). The GDP on the average stood at (26.3 billion US dollar). The result on the foreign sector put average exports of goods and services to about ( 6.12 billion US dollar) while the imports of goods and services on the average stood at about (5.48 billion US dollar). The economy grew at the average rate of $(5.8 \%)$, while the government spending and inflation grew at the same rate of about $(6.6 \%)$. The import grew at a higher average rate of about $(6.7 \%)$ while the export grew at an average rate of about $(6.5 \%)$. The population grew at an average rate of $(2.75 \%)$, while unemployment rate grew at an average rate of about $(4.57 \%)$. The range, standard deviation, and coefficient of variation are all measures of dispersion. The range shows the difference between the maximum and minimum value. The range for each of the variables is computed as shown in Table 1. It can be observed how far the maximum value is from the minimum value.

Table 1. Descriptive Summary of the Study Variables

\begin{tabular}{|l|c|c|c|c|c|c|c|c|c|}
\hline Statistic & $G S^{*}$ & $C P I$ & $G D P^{*}$ & $E X P T N^{*}$ & $I M P T N^{*}$ & $\begin{array}{c}E X C R T \\
\text { LCU/USD }\end{array}$ & $\begin{array}{c}\text { PGRT, } \\
\mathbf{\%}\end{array}$ & $\begin{array}{c}T I N T, \\
\mathbf{\%}\end{array}$ & $\begin{array}{c}\text { UEMRT, } \\
\mathbf{\%}\end{array}$ \\
\hline Mean & 2.22 & 82.86 & 26.3 & 6.12 & 5.48 & 606.25 & 2.75 & 0.57 & 4.55 \\
\hline Median & 0.64 & 81.96 & 4.88 & 1.19 & 1.94 & 496.37 & 2.71 & 0.55 & 4.01 \\
\hline Maximum & 37.8 & 255.10 & 568 & 145.0 & 88.90 & 7931.63 & 4.63 & 1.18 & 11.71 \\
\hline Minimum & 0.016 & 2.55 & 0.21 & 0.011 & 0.074 & 0.04 & -0.44 & 0.21 & 0.27 \\
\hline Range & 37.78 & 252.55 & 567.79 & 144.99 & 88.83 & 7931.59 & 5.07 & 0.97 & 11.44 \\
\hline Std. Dev. & 5.63 & 37.15 & 78.6 & 16.80 & 11.8 & 942.64 & 0.61 & 0.18 & 2.70 \\
\hline Coeff. of var & $\mathbf{2 . 5 4}$ & $\mathbf{0 . 4 5}$ & $\mathbf{2 . 9 9}$ & $\mathbf{2 . 7 5}$ & $\mathbf{2 . 1 5}$ & $\mathbf{1 . 5 5}$ & $\mathbf{0 . 2 2}$ & $\mathbf{0 . 3 2}$ & $\mathbf{0 . 5 9}$ \\
\hline Skewness & 4.85 & 0.80 & 4.80 & 5.23 & 4.21 & 4.70 & -0.47 & 0.76 & 0.66 \\
\hline Kurtosis & 27.02 & 6.22 & 26.45 & 33.99 & 22.33 & 28.89 & 10.58 & 3.44 & 2.64 \\
\hline $\begin{array}{l}G S-\text { government expenditure, } C P I-\text { Consumer prices, } G D P-\text { gross domestic product, EXPTN- exports of goods and } \\
\text { services, IMPTN - imports of goods and services, EXCRT-exchange rate, PGRT-population growth rate, } T I N T-\text { nominal } \\
\text { interest rate, and UEMRT - unemployment rate. } \\
\text { * Amount stated in US\$ billion. }\end{array}$ \\
Source: Authors' compilation, 2021. \\
\hline
\end{tabular}

The coefficient of variation, which is obtained as a standard deviation-mean ratio reveals how far apart from the mean each of the variables is in terms of their distribution. A variable with coefficient of variation less than 1 is said to exhibit a low variance in its distribution, which can imply that the variable does not differ significantly across the countries studied. A variable with coefficient of variation 
greater than 1 exhibits a high variance in its distribution. It can imply that the variable differs significantly across the countries studied.

In Table 1, inflation rate, population growth rate, interest rate, and unemployment rate are characterized with low variance since their coefficient of variation is less than 1 . This could mean that the studied countries are not significantly different from one another on these variables. On the other hand, variables such as government spending, gross domestic product, exports, imports, and exchange rate are characterized with high variance since the coefficient of variation for each of these variables is greater than 1 . This can also imply that the countries studied differ significantly by these aforementioned variables. The means of the variables such as consumer price index, population growth rate, interest rate, and unemployment rate are found to be greater than their standard deviations. This implies that the data on these variables cluster around the mean. For other variables such as government spending, gross domestic product, exports, imports, and exchange rate, the mean of each of these variables is less than the standard deviation. The data on these variables are widely dispersed.

The measure of asymmetry reveals that a population growth rate is negatively skewed since the skewness is negative for this variable. Other variables are positively skewed. The measure of Kurtosis for unemployment rate is 2.64 . It is less than the threshold of 3 . The distribution is platykurtic, indicating that the variables are steep at the top. However, for each of the other variables, the measure of Kurtosis is found to be greater than the threshold value of 3 showing that each of the other variables is leptokurtic.

\subsection{The Unit Root Test}

Panel unit root tests were conducted to determine the order of integration of each of the variables. These tests verified the stationarity condition of the variables. The two most widely used panel unit root tests are Levin, Lin, and Chu (LLC) unit root test and Im, Pesaran, and Shin (IPS) unit root test. The absence of unit root in a variable indicates that the variable is stationary at the level. Recent development in econometrics has offered different approaches to modelling variables based on whether they are stationary at the levels, first differences, or second differences. Once the order of integration is ascertained, it becomes easy to determine whether the proposed methodology is appropriate or not.

This study employs LLC and IPS unit root tests and the result obtained are presented in Table 2. It is clear that the variables have mixed order of integration. Three of the variables: GDP growth rate, growth rate of consumer prices, and population growth rate were level stationary, and thus, followed the $I(0)$ process. Other variables such as government spending, money supply, exports of goods and services, imports of goods and services, trade volume, exchange rate of local currency to US dollar, interest rate and unemployment rate were first difference stationary, having $I(1)$ order of integration. There is no $I(2)$ variable in the set. Hence, panel ARDL becomes appropriate to determine the long-run behaviour and short-run dynamics characterising the models. 
Table 2. Result of LLC and IPS Panel Unit Root Tests

\begin{tabular}{|c|c|c|c|c|c|c|c|c|c|}
\hline \multirow{3}{*}{ Variables } & \multicolumn{4}{|c|}{ Levin, Lin, and Chu $t^{*}$} & \multicolumn{4}{|c|}{ Im, Pesaran, and Shin $W$-stat } & \multirow{3}{*}{$\begin{array}{l}\text { Order of } \\
\text { Integ- } \\
\text { ration }\end{array}$} \\
\hline & \multicolumn{2}{|c|}{ Level } & \multicolumn{2}{|c|}{ First Difference } & \multicolumn{2}{|c|}{ Level } & \multicolumn{2}{|c|}{ First Difference } & \\
\hline & Statistic & Prob & Statistic & Prob & Statistic & \begin{tabular}{|l|} 
Prob \\
\end{tabular} & Statistic & Prob & \\
\hline $\ln G S^{\mathrm{tc}}$ & -0.9249 & 0.1775 & $-6.7763^{*}$ & 0.0000 & -1.2983 & 0.0971 & $-6.5613^{*}$ & 0.0000 & $\mathrm{I}(1)$ \\
\hline $\ln C P I^{\mathbf{t c}}$ & $-5.5179^{*}$ & 0.0000 & - & - & $-4.0632 *$ & 0.0000 & - & - & $\mathrm{I}(0)$ \\
\hline $\ln M S^{\mathrm{tc}}$ & 0.6470 & 0.7412 & $-6.9283^{*}$ & 0.0000 & 0.9213 & 0.8216 & $-7.6910 *$ & 0.0000 & $\mathrm{I}(1)$ \\
\hline $\ln E X P T N^{\text {tc }}$ & 0.1988 & 0.5788 & $-6.2023^{*}$ & 0.0000 & -1.2725 & 0.1016 & $-8.1438^{*}$ & 0.0000 & $\mathrm{I}(1)$ \\
\hline $\ln I M P T N^{\text {tc }}$ & -0.0763 & 0.4696 & $-6.3039^{*}$ & 0.0000 & -1.2722 & 0.1017 & $-7.1758^{*}$ & 0.0000 & $\mathrm{I}(1)$ \\
\hline $\ln E X I M G D P$ & 0.1988 & 0.5788 & -6.2023 & 0.0000 & -1.2725 & 0.1016 & -8.1438 & 0.0000 & $\mathrm{I}(1)$ \\
\hline $\ln G D P^{\mathrm{tc}}$ & $-2.0945^{* *}$ & 0.0181 & - & - & -2.2825 & $0.0112 * *$ & - & - & $\mathrm{I}(0)$ \\
\hline$E X C R T^{\mathbf{c}}$ & -1.3074 & 0.0955 & $-6.5581^{*}$ & 0.0000 & -1.4881 & 0.0684 & $-6.2487^{*}$ & 0.0000 & $\mathrm{I}(1)$ \\
\hline$P G R T^{\mathbf{c}}$ & -11.7533 & 0.0000 & - & - & -16.2362 & 0.0000 & - & - & $\mathrm{I}(0)$ \\
\hline$T I N T^{\mathbf{t c}}$ & 0.1611 & 0.5640 & $-5.6515^{*}$ & 0.0000 & 0.5013 & 0.6919 & $-9.2349^{*}$ & 0.0000 & $\mathrm{I}(1)$ \\
\hline$U E M R T^{\mathbf{t c}}$ & -0.9924 & 0.1605 & $-3.6872^{*}$ & 0.0000 & -1.1524 & 0.1246 & $-3.7741^{*}$ & 0.0001 & $\mathrm{I}(1)$ \\
\hline \multicolumn{10}{|c|}{$\begin{array}{l}*, * * \text { Indicates significance at } 1 \% \text { and } 5 \% \text {, respectively. }{ }^{\text {tc }} \text { Indicates test conducted with intercept and trend. } \\
\ln G S, \ln C P I, \ln M S, \ln E X P T N, \ln I M P T N, \ln E X I M G D P \text { and } \ln G D P \text { are the natural log of variables; government spending, } \\
\text { consumer price index, money supply, exports, imports, trade volume and gross domestic product, respectively. EXCRT is } \\
\text { a real effective exchange rate, PGRT is the population growth rate, TINT is an interest rate, while UEMRT is an } \\
\text { unemployment rate. }\end{array}$} \\
\hline
\end{tabular}

\subsection{Empirical Evidence from Static Panel Regression Analysis}

To establish some empirical evidence on the direction and strength of association between government spending and inflation, output, money supply, among other variables, static panel regression is first used. There are three models estimated in this case. The first model is the model with common constant, the second one is the fixed effects model, and the third model is the random effects model. The result is presented in Table 3. Inflation has a positive effect on government spending in all three models. This implies that an inflation rate induces the rate of government spending, as the rate of inflation rises, the rate of government spending also rises responsively.

Table 3. The Result from Panel Least Square Estimate

\begin{tabular}{|c|c|c|c|c|c|c|}
\hline \multicolumn{7}{|c|}{ Dependent variable: $\ln G S$} \\
\hline \multirow{2}{*}{ Variable } & \multicolumn{2}{|c|}{ Common constant } & \multicolumn{2}{|c|}{ Fixed effects } & \multicolumn{2}{|c|}{ Random effects } \\
\hline & Coefficient & $t$-stat (prob) & Coefficient & $t$-stat (prob) & Coefficient & $t$-stat (prob) \\
\hline$C$ & -1.580487 & $-1.80(0.073)$ & -8.955932 & $-7.35(0.000)$ & -3.312866 & $-3.87(0.000)$ \\
\hline $\ln C P I$ & 0.151348 & $2.75(0.006)$ & 0.043535 & $0.53(0.597)$ & 0.147103 & $2.77(0.006)$ \\
\hline $\ln G D P$ & 0.125927 & $0.34(0.734)$ & 2.249524 & $6.33(0.000)$ & 1.121398 & $3.55(0.000)$ \\
\hline $\ln M S$ & 0.064831 & $3.23(0.001)$ & -0.033433 & $-0.54(0.592)$ & 0.034152 & $1.15(0.253$ \\
\hline $\ln E X P T N$ & -0.190989 & $-1.15(0.252)$ & -0.327943 & $-2.41(0.017)$ & -0.207327 & $-1.56(0.120)$ \\
\hline $\ln I M P T N$ & 0.975881 & $3.84(0.000)$ & -0.689918 & $-2.81(0.005)$ & 0.038999 & $0.18(0.861)$ \\
\hline EXCRT & -0.000134 & $-4.10(0.000)$ & -0.000042 & $-1.05(0.295)$ & -0.000073 & $-2.12(0.035)$ \\
\hline$P G R T$ & 0.121130 & $2.78(0.006)$ & 0.052206 & $1.18(0.239)$ & 0.075852 & $1.88(0.061)$ \\
\hline UEMRT & 0.004830 & $0.43(0.671)$ & 0.000654 & $0.04(0.967)$ & 0.005437 & $0.41(0.681)$ \\
\hline TINT & -0.584435 & $-0.88(0.381)$ & 1.544142 & $2.58(0.010)$ & 0.411157 & $0.74(0.462)$ \\
\hline$R^{2}$ & \multicolumn{2}{|c|}{0.914} & \multicolumn{2}{|c|}{0.956} & \multicolumn{2}{|c|}{0.855} \\
\hline $\bar{R}^{2}$ & \multicolumn{2}{|c|}{0.912} & \multicolumn{2}{|c|}{0.953} & \multicolumn{2}{|c|}{0.851} \\
\hline $\begin{array}{l}G S-\text { gover } \\
\text { services, } I M \\
\text { nominal int }\end{array}$ & exnenditure & $\begin{array}{l}C P I-\text { consum } \\
\text { goods and serv } \\
M R T-\text { unemplo }\end{array}$ & $G D P$ & $\begin{array}{l}\text { ss domestic pro } \\
\text { nge rate, } P G R T \\
\text { ral logarithm. }\end{array}$ & $X P T N-$ & $\begin{array}{l}\text { rts of goods and } \\
\text { rate, TINT - }\end{array}$ \\
\hline
\end{tabular}


However, the relationship is only significant in the model with common constant as well as in the model with random effects. It is not significant in the model with fixed effects. Other variables such as GDP growth rate, money supply, import growth rate, population growth rate, and unemployment rate have positive effects on government spending in models with constant term and random effects but not in the case with the fixed effects model. The assumption of a common constant in the panel may be relaxed since there is the possibility of having country specific characteristics and this lends support to the fixed effects or random effects model. The sign of the parameters are not the same comparing the result of the fixed effects model with the common effects and the fixed effects models. It becomes necessary to find out which of the two models is appropriate for adoption.

\subsection{Choosing between the Fixed and Random Effects Models}

To choose the appropriate model between the fixed and random effects models, the study conducts the Hausman test. This test has been widely used in the panel econometric literature to detect which model is appropriate between the fixed and random effects models. The result of Hausman test is shown in Table 4. The $p$-value for the test is less than $1 \%$. This indicates that the random effects model is not appropriate, in preference to the fixed effects specification.

Table 4. The Result of Hausman Test

\begin{tabular}{|c|c|c|c|}
\hline Test Summary & $\chi^{2}$-statistic & $\chi^{2}$-d.f. & $p$-value \\
\hline Cross-section random & $83.25^{*}$ & 9 & 0.000 \\
\hline \multicolumn{4}{|c|}{ * Indicates significant at $1 \%$} \\
\hline
\end{tabular}

In Table 3, the fixed effect model is considered an appropriate model to adopt. However, this result cannot be taken too far since static models are less effective in the actualization of the objective of this study. The objectives would be better achieved with the use of dynamic models. This study uses the panel ARDL to capture the long-run as well short-run effects.

\subsection{Panel ARDL Approach}

In order to separate the short-run from the long-run by capturing the equilibrium adjustment from short-run to the long-run, panel ARDL is used. Government spending enters the model specification as an endogenous variable with an optimal lag of one, as automatically selected by the system based on the Schwarz criterion. Inflation enters as a dynamic explanatory variable with an optimal lag of 2, based on the Schwarz criterion. The other two variables: gross domestic product used to proxy output, and money supply are added as dynamic explanatory variables with the same optimal lag. Other variables enter as fixed exogenous variables. Tables 5 and 6 display the short-run and long-run, respectively, effects of inflation, GDP, and money supply with due consideration to export growth rate, import growth rate, exchange rate, population growth rate, interest rate, and unemployment rate on government spending. 


\subsubsection{The Short-Run ARDL Model Estimate}

In Table 5, GDP and import have a positive and significant effect on government spending in the short run. The error correction term is negative, less than an absolute value of 1 and significant. The term satisfies its underlying requirement. The coefficient also shows that there is a high speed of adjustment. For instance, the result shows that about $72 \%$ of disequilibria in the previous year is corrected for in the current year. It means that the disequilibria correction period is about 1.5 years. Variables return to equilibrium shortly after deviation from equilibrium.

Table 5. Result of Short-Run ARDL Model Estimate

\begin{tabular}{|l|l|l|l|}
\hline \multicolumn{4}{|l}{ Dependent Variable: $\Delta \ln G S$} \\
\hline Variable & Coefficient & $\boldsymbol{t}$-statistic & $\boldsymbol{p}$-value \\
\hline $\boldsymbol{C}$ & -7.091989 & $-3.229927 *$ & 0.0000 \\
\hline$\Delta \ln C P I$ & -0.134771 & -0.643701 & 0.5205 \\
\hline$\Delta \ln G D P$ & 0.176638 & $1.878081 * * *$ & 0.0618 \\
\hline$\Delta \ln M S$ & -0.046914 & -0.362954 & 0.7170 \\
\hline $\ln E X P T N$ & -0.093188 & -0.940764 & 0.3480 \\
\hline $\ln I M P T N$ & 0.197358 & $2.492325 * *$ & 0.0135 \\
\hline$P G R T$ & 0.580645 & 0.856895 & 0.3925 \\
\hline$E X C R T$ & 0.002122 & 1.475742 & 0.1416 \\
\hline$U E M R T$ & 0.090380 & 1.390944 & 0.1658 \\
\hline$T I N T$ & -0.235011 & -1.224111 & 0.2223 \\
\hline$E C M(-1)$ & -0.722694 & $-8.180148^{*}$ & 0.0014 \\
\hline $\begin{array}{l}* \\
\text { respectively. }\end{array} *$ Indicates significant at $1 \%, 5 \%$ and $10 \%$ level, \\
\hline
\end{tabular}

\subsubsection{The Long-Run ARDL Model Estimate}

The result presented in Table 6 shows that inflation is significant and has negative effects on government spending. This result remains the same with the short run in terms of sign but while these variables are not significant in the short run, inflation on its own is highly significant in explaining government spending dynamics in the long run. This corroborates with the findings of Magazzino (2011) for Portugal; Georgantopoulos and Tsamis (2010) for Cyprus; Olayungbo (2013) for Nigeria; Attari and Javed (2013) for Pakistan; Bwire and Nampewo (2014), and Ssebulime and Edward (2019) for Uganda.

GDP has a positive and highly significant effect on government spending in the long-run lending support to what is generally called the Wagner hypothesis in public economics literature. It has been verified theoretically and empirically that as per capita income increases, the government role increases both intensively and extensively in response to rising level of income suggesting a functional relationship between government spending and economic growth (Akinlo, 2013; Dada and Oguntegbe, 2013; Paparas et al., 2019). 
Table 6. Result of Long-Run Model Estimate

\begin{tabular}{|c|c|c|c|}
\hline \multicolumn{4}{|c|}{ Dependent Variable: $\Delta \ln G S$} \\
\hline Variable & Coefficient & $t$-statistic & $p$-value \\
\hline $\ln C P I$ & -0.308006 & $-3.981733^{*}$ & 0.0001 \\
\hline $\ln G D P$ & 1.221692 & $4.908540^{*}$ & 0.0000 \\
\hline $\ln M S$ & -0.059421 & -1.583075 & 0.1150 \\
\hline
\end{tabular}

\subsubsection{Causality Relation in the Short Run}

The study explored the short-run causal evidence and the result obtained is presented in Table 7. There is evidence of short-run causality among the variables of interest, for instance, a unidirectional causality flow from government spending to inflation, from money supply to inflation and from money supply to GDP. The result also shows that there is a short-run bidirectional causality between GDP and inflation. However, no short-run causal evidence is found between government spending and GDP, and between government spending and money supply. The result of short-run causality from government spending to inflation agrees with that of Magazzino (2011) for Cyprus, Italy, Malta, and Spain. It also agrees with the finding of Bwire and Nampewo (2014), Ssebulime and Edward (2019) for Uganda.

Table 7. Result of Short-Run Causality

\begin{tabular}{|c|c|c|c|c|c|c|c|c|c|c|c|c|}
\hline \multirow{2}{*}{$\begin{array}{l}\text { Dependent } \\
\text { Variable }\end{array}$} & \multicolumn{3}{|c|}{$\Delta \ln G S$} & \multicolumn{3}{|c|}{$\triangle \ln C P I$} & \multicolumn{3}{|c|}{$\Delta \ln G D P$} & \multicolumn{3}{|c|}{$\Delta \ln M S$} \\
\hline & $W$-stat & Z-bar & Prob. & $W$-stat & Z-bar & Prob. & $W$-stat & Z-bar & Prob. & $W$-stat & Z-bar & Prob. \\
\hline$S$ & - & - & - & 1.899 & -0.450 & 0.653 & 2.748 & 0.733 & 0.464 & 3.078 & 1.194 & 0.233 \\
\hline & 3.898 & 2.337 & 0.019 & - & - & - & 6.974 & 6.625 & 0.000 & 3.486 & 1.762 & 0.078 \\
\hline & 2.578 & 0.495 & 0.620 & 3.634 & 1.969 & 0.049 & - & - & - & 3.512 & 1.799 & 0.072 \\
\hline$\triangle \ln M S$ & 2.153 & -0.097 & 0.923 & 2.683 & 0.642 & 0.521 & 1.437 & -1.095 & 0.274 & - & - & - \\
\hline \multicolumn{13}{|c|}{$\begin{array}{l}\text { DIRECTION OF CAUSALITY IN THE SHORT RUN: } G S \rightarrow C P I ; G S-G D P ; G S-M S ; G D P \leftrightarrow C P I ; M S \rightarrow C P I ; \\
M S \rightarrow G D P \text {. }\end{array}$} \\
\hline \multicolumn{13}{|c|}{$\begin{array}{l}\Delta \ln G S-\log \text { difference of government spending, } \Delta \ln C P I-\log \text { difference of consumer price index, } \Delta \ln G D P \\
-\log \text { difference of gross domestic product, } \Delta \ln M S-\log \text { difference of money supply. }\end{array}$} \\
\hline
\end{tabular}

\subsubsection{The Direction of Causality in the Long Run}

The study conducts a long-run causality test in a bivariate setting to account for the direction of causality between each pair of variables in the long run. The result obtained is shown in Table 8. A bi-directional causality between government spending and inflation, government spending and money supply, GDP and inflation, as well as GDP and money supply is established. The results also indicate a unidirectional causality between government spending and GDP as well as money supply and inflation. Causality flows from money supply to inflation but not the other way round. There is no feedback or reverse causation from inflation to money supply. 
While Magazzino (2011) found a unidirectional causality flow from inflation to government spending for Italy, the result of this study for the ECOWAS region diverges a little bit by confirming a long-run bidirectional causality between government spending and inflation. It implies that both variables are functionally dependent. Inflation is found to be a result of government spending growth. It is found as a cause of growth in government spending. In this case, fiscal policy dynamics are important in explaining the dynamics of prices in the affected countries.

Table 8. Result of Long-Run Causality Test

\begin{tabular}{|c|c|c|c|c|c|c|c|c|c|c|c|c|}
\hline \multirow{2}{*}{\begin{tabular}{l|} 
Dependent \\
Variable
\end{tabular}} & \multicolumn{3}{|c|}{$\ln G S$} & \multicolumn{3}{|c|}{$\ln C P I$} & \multicolumn{3}{|c|}{$\ln G D P$} & \multicolumn{3}{|c|}{$\ln M S$} \\
\hline & $W$-stat & Z-bar & Prob. & $W$-stat & Z-bar & Prob. & $W$-stat & Z-bar & Prob. & $W$-stat & Z-bar & Prob. \\
\hline $\ln G S$ & - & - & - & 9.069 & 9.670 & 0.000 & 5.114 & 4.094 & 0.000 & 8.416 & 8.750 & 0.000 \\
\hline $\ln C P I$ & 7.184 & 7.013 & 0.000 & - & - & - & 7.926 & 8.059 & 0.000 & 4.586 & 3.350 & 0.000 \\
\hline $\ln G D P$ & 2.116 & -0.133 & 0.894 & 11.963 & 13.750 & 0.000 & - & - & - & 8.077 & 8.272 & 0.000 \\
\hline $\ln M S$ & 4.028 & 2.562 & 0.010 & 1.248 & -1.357 & 0.175 & 4.606 & 3.377 & 0.001 & - & - & - \\
\hline \multicolumn{13}{|c|}{$\begin{array}{l}\text { DIRECTION OF CAUSALITY IN THE LONG RUN: } G S \leftrightarrow C P I ; G S \leftarrow G D P ; G S \leftrightarrow M S ; G D P \leftrightarrow C P I ; M S \rightarrow C P I ; \\
M S \leftrightarrow G D P .\end{array}$} \\
\hline
\end{tabular}

\section{CONCLUSION}

This study has examined the dynamic nexus among government spending, price, output, and money amidst other variables, including exchange rate, interest rate, unemployment rate, and population growth rate in twelve ECOWAS countries using a panel ARDL and causality modelling approach. The study dropped three countries for data availability on all included variables within the period covered. Since the study has adopted a balanced panel, countries must have data on all variables from the initial time to the end time. The twelve countries included in the analysis are Benin, Burkina-Faso, Cameroun, Cote d'Ivoire, The Gambia, Ghana, Guinea-Bissau, Mali, Niger, Nigeria, Serra-Leone, and Togo.

Data have been gathered on variables such as total government expenditure, consumer price index, real GDP, and money supply. Other variables include import and export of goods and services, exchange rate, interest rate, unemployment rate, and population growth rate. The study has covered the period of 1991-2019. The study has examined the statistical properties of the data series for each variable by engaging in descriptive analysis as well as unit root tests to account for the stationarity conditions of the variables and the order of integration. The result has shown a positive relationship between government spending and GDP, government spending and import, government spending and exchange rate, government spending and unemployment rate, and government spending and population growth rate.

However, the result has shown a negative relationship between government spending and inflation, government spending and money supply, government spending and export as well as government spending and interest rate. Other results 
of the study have shown short-run unidirectional causality from government spending to inflation, money supply to inflation as well as money supply to GDP. Short-run bidirectional causality exists between GDP and inflation. No short-run causal evidence exists between government spending and GDP nor between government spending and money supply. The long-run Granger causality test has shown bidirectional causality between government spending and inflation, government spending and money supply, GDP and inflation as well as GDP and money supply. However, unidirectional causality has been found running from GDP to government spending, and money supply to inflation.

The overall implication of this study is that, in the long run, an increase in government spending will lower inflation and raise GDP of the region. The study, therefore, concludes that an increase in import of goods and services, unemployment rate, exchange rate, and population growth rate will raise government spending in the short run, while the increase in government spending will reduce inflation and enhance economic growth of the region in the long run.

\section{REFERENCES}

Akinlo, A. E. (2013). Government Spending and National Income Nexus for Nigeria. Global Journal of Business Research, 7(1), 33-41.

Aksoy, Y., \& Melina, G. (2011). US Fiscal Indicators, Inflation, and Output. North American Journal of Economics and Finance, 22(3), 221-236. https://doi.org/10.1016/j.najef.2011.02.001

Attari, M. I. J., \& Javed, A. Y. (2013). Inflation, Economic Growth and Government Expenditure of Pakistan: 1980-2010. Procedia Economics and Finance, 5, 58-67. https://doi.org/10.1016/S2212-5671(13)00010-5

Bwire, T., \& Nampewo, D. (2014). Fiscal Deficit Financing: Implications for Monetary Policy Formulation in Uganda. Journal of Applied Finance and Banking, 4(2), 125-138.

Dada, M. A., \& Abalaba, B. P. (2013) Government Expenditure Growth and Inflation in Nigeria: Any Evidence of Causality? Proceedings of Second Interdisciplinary International Conference (vol. 2, iss. 3). Emmanuel Ebitimi Banigo Auditorium, University of Port-Harcourt, Nigeria, November 19-22, 2013.

Dada, M. A., \& Oguntegbe, A. O. (2013). Is Wagner's Law a Myth or a Reality? Empirical Evidence from Nigeria. International Journal of Development Sustainability, 1(1), 123-137.

Dada, M. A., Posu, S. M. A., \& Maghori, E. S. (2017). Modelling Inflation and Economic Growth in Five ECOWAS Countries; A Bivariate Analysis. International Journal of Economics Review \& Business Research, 4(2), 47-67.

Dumitrescu, E.-I., \& Hurling, C. (2012), Testing for Granger Non-Causality in Heterogeneous Panels, Economic Modelling, 29(4), 1450-1460. https://doi.org/10.1016/j.econmod.2012.02.014

Ezirim, B. C., \& Ofurum, C. O. (2003). Public Expenditure Growth and Inflation in Developed and Less Developed Countries. Nigerian Business and Social Review, 2(1), 75-94.

Ezirim, B. C., Muoghalu, M. I., \& Elike, U. (2008). Inflation versus Public Expenditure Growth in the US: An Empirical Investigation, North American. Journal of Finance and Banking Research, 2(2), 26-40.

Georgantopoulos, A. G., \& Tsamis, A. (2010). The Interrelationship between Money Supply, Prices, Government Spending, and Economic Growth: A Causality Analysis for the Case of Cyprus. International Journal of Economics Sciences and Applied Research, 5(3), 115-128.

Im, K. S., Pesaran, M. H., \& Shin, Y. (2003). Testing for Unit Roots in Heterogeneous Panels, Journal of Econometrics, 115, 53-74. https://doi.org/10.1016/S0304-4076(03)00092-7

Kia, A., (2006). Deficits, Debt Financing, Monetary Policy and Inflation in Developing Countries: Internal or External Factors? Evidence from Iran. Journal of Asian Economics, 17, 879-903. https://doi.org/10.1016/j.asieco.2006.08.011 
Levin, A., Lin, C. F., \& Chu, C. S. (2002). Unit Root Tests in Panel Data: Asymptotic and FiniteSample Properties. Journal of Econometrics, 108(1), 1-24. https://doi.org/10.1016/S03044076(01)00098-7

Magazzino, C. (2011). The Nexus between Public Expenditure and Inflation in the Mediterranean Countries. Munich Personal RePEc Archive (MPRA), Paper No. 28493.

Mallik, G., \& Chowdhury, A. (2001). Inflation and Economic Growth: Evidence from Four South Asian Countries. Asia-Pacific Development, 8(1), 123-135.

Olayungbo, D. O. (2013). Government Spending and Inflation in Nigeria: An Asymmetry Causality Test. International Journal of Humanities and Management Sciences, 1(4), 238-242.

Ozurumba, B. A. (2012). Fiscal Deficits and Inflation in Nigeria: The Causality Approach. International Journal of Scientific and Technology Research, 1(8), 6-12.

Paparas, D., Richter, C., \& Kostakis, I. (2019). The Validity of Wagner's Law in the United Kingdom during the Last Two Centuries. International Economics and Economic Policy, 16, 269-291. https://doi.org/10.1007/s10368-018-0417-7

Pekarski, S. (2011). Budget Deficits and Inflation Feedback. Structural Change and Economic Dynamics, 22(1), 1-11. https://doi.org/10.1016/j.strueco.2010.09.002

Ssebulime, K., \& Edward, B. (2019) Budget Deficit and Inflation Nexus in Uganda 1980-2016: A Cointegration and Error Correction Modeling Approach. Journal of Economics Structures, 8(3), 1-14. https://doi.org/10.1186/s40008-019-0136-4

Tehranchian, A. M., Samimi, A. J., \& Behravesh, M. (2010). Government Size, Inflation, and Economic Growth in Iran. Australian Journal of Basic and Applied Sciences, 4(8), 3934-3937.

\section{AUTHORS' SHORT BIOGRAPHIES}

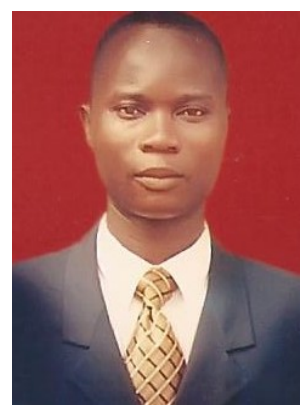

Matthew A. Dada received the PhD degree in economics, in 2016, from Obafemi Awolowo University, Ile-Ife Nigeria. From the same institution, he also received M.Sc. (economics) in 2012, Master of Business Administration (general management) in 2008, Master of Education (tests and measurements) in 2006, and B.Sc. (economics) in 1997. Prior to all these degrees, he received the Nigeria Certificate in Education (mathematics and economics) from Osun State College of Education Ilesa, Nigeria in 1991. He is a lecturer in the Department of Economics at Federal University of Agriculture, Abeokuta., Nigeria. Previously, he was a lecturer in the Department of Economics at Wellspring University, Benin City, Nigeria. He has published a reasonable number of papers in referred journals in the field of public, energy, international and development economics.

E-mail: dadama@,funaab.edu.ng

ORCID iD: http://orcid.org/0000-0002-2080-6082

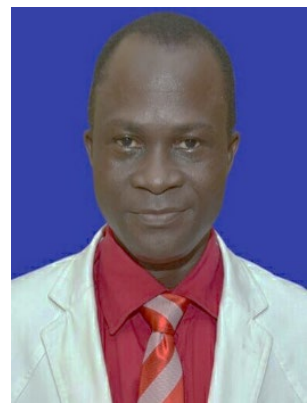

Sunday M. A. Posu received the $\mathrm{PhD}$ degree in economics from Obafemi Awolowo University, Ile-Ife, Nigeria in 2014. Earlier, he received the M.Phil. (economics), and the M.Sc. (economics) degrees from University of Ibadan, Nigeria in 2008 and 1997, respectively. In 1991, he received the B.Sc. (economics) degree from Ogun State University (now Olabisi Onabanjo University), Ago-Iwoye, Nigeria. He is, currently, a lecturer in the Department of Economics at Federal University of Agriculture, Abeokuta, and previously worked as a lecturer at Osun State University, Osogbo, and OOU, Ago-Iwoye, Nigeria. His research interests with appreciable number of publications in referred journals are on environmental economics, international economics, and public sector economics.

E-mail: posusma@,funaab.edu.ng

ORCID iD: https://orcid.org/0000-0001-7284-8826 


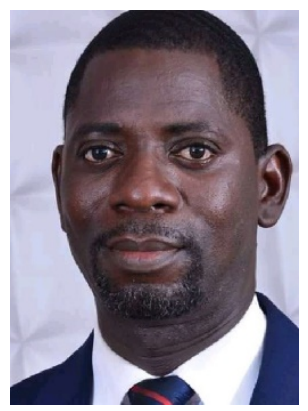

Osaretin G. Okungbowa received the $\mathrm{PhD}$ (economics) degree from the University of Benin, Benin City, Nigeria in 2020. He also obtained the M.Sc. (economics), the Master in Business Administration (finance), and the B.Sc. (mathematics and economics) degrees in 2012, 2013 and 2000, respectively from the same university. Presently, he is a Research Fellow at the National Institute for Legislative and Democratic Studies, National Assembly, Nigeria. He previously worked as a lecturer in the Department of Economics at Wellspring University, Benin City, Nigeria. He has a reasonable number of journal articles published in referred journals in the field of international economics and development economics.

Email: Osaretin.okungbowa@gmail.com

ORCID iD: https://orcid.org/0000-0002-2089-7279

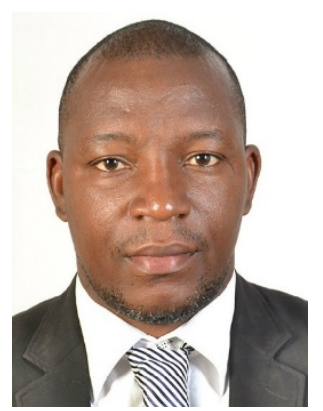

Bamidele P. Abalaba received the M.Phil (economics) degree in 2016 from Obafemi Awolowo University Ile-Ife, Nigeria. He also received the M.Sc. (economics) and B.Sc. (economics) from Lagos State University, Ojo, Nigeria in 2008 and 2000, respectively. $\mathrm{He}$ is a $\mathrm{PhD}$ student in the Department of Applied Economics, School of Economics, Kenyatta University Nairobi, Kenya. Although a PhD student, he is also a lecturer in the Department of Economics, Osun State University, Osogbo, Nigeria. He previously worked with the Citizenship \& Leadership Training Center. (C\&LTC) Abuja, Nigeria, and the Industrial Training Fund, Jos Plateau, Nigeria. He has published journal articles in areas of interest including labour economics, energy economics, and international economics.

Contact: Department of Economics, Osun State University, Osogbo, Nigeria.

E-mail: abalabapero@yahoo.com

ORCID iD: https://orcid.org/0000-0001-6708-3814 